International Journal of Lakes and Rivers.

ISSN 0973-4570 Volume 13, Number 2 (2020), pp. 131-148

(C) Research India Publications

https://dx.doi.org/10.37622/IJLR/13.2.2020.131-148

\title{
Heavy Metal Pollution Monitoring of Yamuna from Dak Patthar to Agra
}

\author{
Rahat Zehra*, Madhulika Singh ${ }^{1}$, Jyoti Verma ${ }^{2}$ \\ ${ }^{*}$ Research Scholar, Amity University, Amity Institute of Geo Informatics and Remote \\ Sensing, , Noida, Uttar Pradesh - 201313, India. \\ ORCID I'd:- 0000-0002-2042-050X. \\ ${ }^{1}$ Advisor, Amity University, Amity Institute of Geo Informatics and Remote Sensing, \\ Noida, Uttar Pradesh - 201313, India. \\ ${ }^{2}$ Assistant Professor, University of Allahabad, Prayagraj, Uttar Pradesh- 211002, \\ India. ORCID I'd:- 0000-0002-0503-5996.
}

\begin{abstract}
With 14 sampling sites between Dak Patthar to Agra, first time an attempt is made to evaluate the heavy metals viz. Iron, Copper, Zinc, and Manganese in the Yamuna using Indices; Heavy Metal Pollution Index (HPI); Heavy Metal Evaluation Index (HEI), Contamination index (Cd), Principal Component Analysis (PCA), and Cluster analysis (CA).The average concentrations in parts per billion in the increasing order were $\mathrm{Cu}$ (292.7)> $\mathrm{Fe}(309.23)>\mathrm{Mn}$ (475.15) > Zn (3643.9). Resultant average values of HPI 551.40, HEI 12.07, Cd 8.07 with Principal Component1's eigenvalue 55.49 and 2 clusters of sites based on metal concentration were obtained.
\end{abstract}

Keywords- Heavy Metal Pollution Index (HPI), Heavy Metal Evaluation Index (HEI), Contamination Factor $\left(\mathrm{C}_{\mathrm{d}}\right)$, Cluster analysis $(\mathrm{CA})$, Principal Component Analysis (PCA).

\section{INTRODUCTION}

Originating at Yamnotri glacier the Yamuna; along with its tributaries Tons, Betwa, Chambal, Ken, and Sindh contribute to $70.9 \%$ of the catchment area and balance $29.1 \%$ is direct drainage of the main river as reported by the Central Water Commission in 2007. Yamuna catchment basin area shares $40.2 \%$ of the Ganga river basin and in total $10.7 \%$ of the country. The average annual rainfall along the river 
stretch varies from 65 to $125 \mathrm{~cm}$, with the river's annual flow and usage of 10,000 cubic billion meters and $4400 \mathrm{~m} 3 / \mathrm{s}$, respectively (Keshari, 2011).Lots of studies in the literature have focused on heavy metal pollution of water resources all around the world (Nabi bidhendi et al., 2007; Wang et al., 2007; Zhang et al., 2009; Nasrabadi et al., 2010b). The water quality monitoring of River Yamuna has indicated a significant presence of several heavy metals in its water (Rawat et al., 2003; CPCB, 2006; Jain, 2009; Kaur \& Mehra, 2012; Malik et al., 2014). Table1.gives the Concentration of Heavy Metals in various river systems of the Indian subcontinent.

Table1: Concentration of Heavy Metals in various river systems of Indian subcontinent.

\begin{tabular}{|c|c|c|c|c|c|c|c|c|c|c|}
\hline River & $\mathrm{Cr}$ & Cd & $\mathrm{Pb}$ & Mn & $\mathrm{Fe}$ & Co & $\mathrm{Ni}$ & $\mathrm{Cu}$ & Zn & $\begin{array}{c}\text { Reference } \\
\text { S }\end{array}$ \\
\hline Gandak & 19.86 & 0.716 & 15.1 & - - - & -- & 13.66 & 13.91 & 15.37 & 41.315 & $\begin{array}{l}\text { Singh et } \\
\text { al, } 2018\end{array}$ \\
\hline Gandaki & 3.02 & 0.02 & 0.61 & 6.63 & - - - & 0.55 & 1.41 & 1.89 & 127.7 & $\begin{array}{c}\text { Pant et al, } \\
2019\end{array}$ \\
\hline Ganga & 0.013 & 0.009 & 0.04 & -- & -- & -- & -- & 0.019 & 0.072 & $\begin{array}{l}\text { Gupta et } \\
\text { al, } 2008\end{array}$ \\
\hline Ganga & 0.189 & 0.004 & - - - & -- & 1.652 & 0.334 & $\begin{array}{c}0.0028 \\
6\end{array}$ & $\ldots$ & - . & $\begin{array}{c}\text { Sharma et } \\
\text { al, } 2018\end{array}$ \\
\hline Ganga & -- & 0.032 & 0.02 &.- &.- &.- & 0.045 & 0.031 & 0.444 & $\begin{array}{l}\text { Singh et } \\
\text { al,2018 }\end{array}$ \\
\hline Ganga & 261 & 5 & 555 & $-\ldots$ & - & $-\ldots$ & - & 158 & - & $\begin{array}{c}\text { Kumar et } \\
\text { al, } 2019\end{array}$ \\
\hline Ganga & 2.792 & 0.007 & 0.02 & - - - & 0.627 & $-\ldots$ &.- & 0.007 & - & $\begin{array}{c}\text { Ahmad et } \\
\text { al, } 2019\end{array}$ \\
\hline Ganga & 37 & 2.92 & 166.62 & 335.69 & 8074 & 3.4 & 238.7 & 256.36 & 213 & $\begin{array}{l}\text { Singh et } \\
\text { al,2020 }\end{array}$ \\
\hline Ghaghara & 0.007 & 0.043 & 0.01 & - - - & $-\ldots$ & 0.027 & 0.018 & 0.032 & 0.031 & $\begin{array}{l}\text { Singh et } \\
\text { al,2016 }\end{array}$ \\
\hline Gomati & - & - - - & 0.32 & 0.11 & 1.179 & $-\ldots$ & - & 0.016 & 0.168 & $\begin{array}{c}\text { Trivedi et } \\
\text { al, } 2016\end{array}$ \\
\hline Gomati & 0.005 & N.D & 0.039 & 0.0053 & 0.117 & - & 0.017 & N.D & 0.032 & $\begin{array}{l}\text { Singh et } \\
\text { al,2005 }\end{array}$ \\
\hline Kali & 0.09 & 0.08 & 0.19 & - - - & 1.77 & $-\ldots$ & $-\ldots$ & - - - & 29.71 & $\begin{array}{c}\text { Mishra et } \\
\text { al, } 2015\end{array}$ \\
\hline Kali & 0.087 & 0.024 & 0.34 & 0.04 & $-\ldots$ & $-\ldots$ & $-\ldots$ & - - - & 0.079 & $\begin{array}{l}\text { Malik et } \\
\text { al, } 2015\end{array}$ \\
\hline Kosi & 123.0 & 0.59 & 36.1 & -- &.- & 19.59 & 52.65 & 43.63 & 93.36 & $\begin{array}{c}\text { Li et al } \\
2019\end{array}$ \\
\hline Kosi & 1.091 & 0.051 & 0.01 & $\ldots$ & $\ldots$ & 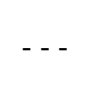 & . & - . - & - & $\begin{array}{l}\text { Idrees et } \\
\text { al, } 2020\end{array}$ \\
\hline Ramganaga & $\ldots$ & 0.0129 & 0.0096 & 1.3091 & 5.2178 & . & - . - & $\ldots$ & 0.1058 & $\begin{array}{c}\text { Khan et al, } \\
2017\end{array}$ \\
\hline
\end{tabular}




\begin{tabular}{|c|c|c|c|c|c|c|c|c|c|c|}
\hline Son & 0.007 & 0.086 & 0.02 & --- & 0.62 & --- & -- & -- & 0.15 & $\begin{array}{c}\text { Ahirwar et } \\
\text { al, } 2015\end{array}$ \\
\hline Yamuna & 0.008 & -- & -- & 0.136 & 0.421 & $\begin{array}{c}0.0006 \\
4\end{array}$ & $\begin{array}{c}0.0180 \\
92\end{array}$ & $\begin{array}{c}0.0018 \\
98\end{array}$ & $\begin{array}{c}0.0034 \\
67\end{array}$ & $\begin{array}{c}\text { Kaur et al, } \\
2012\end{array}$ \\
\hline Yamuna & 147.1 & 47.6 & 116.4 & --- & 10,488 & -- & 375.5 & 2151.8 & 1500.7 & $\begin{array}{l}\text { Bhardwaj } \\
\text { et al, } 2017\end{array}$ \\
\hline Yamuna & 0.035 & 0.037 & 0.02 & --- & 6.467 & -- & 0.0254 & 0.081 & 1.3651 & $\begin{array}{l}\text { Yadav et } \\
\text { al,2019 }\end{array}$ \\
\hline Yamuna & 0.513 & 0.715 & 1.09 & -- & --- & -- & -- & - & 0.948 & $\begin{array}{c}\text { Ghosh et } \\
\text { al, } 2019\end{array}$ \\
\hline Brahmaputra & 0.01 & 0.001 & 0.11 & 1.44 & --- & 0.2 & 0.44 & 0.12 & 0.01 & $\begin{array}{c}\text { Bhuyan et } \\
\text { al, } 2019 \\
\end{array}$ \\
\hline Cauvery & 0.32 & --- & 9.95 & 1.25 & -- & 2.23 & 5.25 & 1.12 & 10.7 & $\begin{array}{c}\text { Begum et } \\
\text { al, } 2009\end{array}$ \\
\hline Godavari & 10.12 & 0.99 & 4.11 & -- & 0.18 & -- & 17.29 & 42.8 & 0.094 & $\begin{array}{c}\text { Hussain et } \\
\text { al, } 2017 \\
\end{array}$ \\
\hline Kameng & N.A & 0.069 & 0.375 & 0.23 & 0.769 & -- & -- & 0.083 & 0.036 & $\begin{array}{c}\text { Sharma et } \\
\text { al, } 2018 \\
\end{array}$ \\
\hline $\begin{array}{c}\text { Mahanadi and } \\
\text { Brahmani }\end{array}$ & N.A & 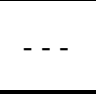 & -- & 1500 & 8000 & 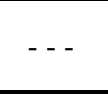 & - & 126 & 272 & $\begin{array}{c}\text { Mishra et } \\
\text { al,2014 }\end{array}$ \\
\hline Mithi & 455 & 223 & 755 & 231 & -- & $-\ldots$ & 607 & -- & -- & $\begin{array}{c}\text { Singare et } \\
\mathrm{al}, 2012 \\
\end{array}$ \\
\hline Subarnarekha & 0.9 & -- & - & 12 & 133.8 & 0.6 & 25.2 & 16.6 & 3.1 & $\begin{array}{c}\text { Giri et al, } \\
2013\end{array}$ \\
\hline Swarna & N.A & 0.17 & 1.48 & -- & -- & -- & 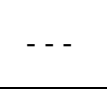 & 4.74 & 9.25 & $\begin{array}{l}\text { Kalra et } \\
\text { al, } 2019\end{array}$ \\
\hline Yamuna & - - & $\ldots$ & $\cdots$ & 0.4751 & 0.3092 & - - & 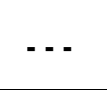 & 0.3230 & 3.6439 & $\begin{array}{l}\text { Present } \\
\text { study }\end{array}$ \\
\hline
\end{tabular}

*concentration in ppm.

The integration of Heavy Metal Pollution Index (HPI); Heavy Metal Evaluation Index (HEI), Contamination index (Cd), Principal Component Analysis (PCA), and Cluster analysis (CA) (Swanson et al. 2001; Arora and Mehra 2009; Vieira et al. 2012; Mohan et al. 1996; Edet and Offiong 2002; Prasad and Mondal 2008) provides detailed, quick, and reliable information for decision-makers to adopt or implement strategies related to water pollution and scarcity (Rawat \& Singh, 2018).

\section{STUDY AREA}

The study area lies between the Dak Patthar (30.502487 N, 77.798393 E) to Agra (27.205341N, 78.036348E) covers polluted areas of the sacred river with the belt of luxuriant alluvial soil and densely inhabited area. The study area and sampling points in parts of the River Yamuna from Dak Patthar to Agra are displayed in Fig1 and Table 2 gives the description of 14 sampling sites. 
Table 2: Description of 14 sampling sites of river Yamuna from Dak Patthar to Agra.

\begin{tabular}{|c|c|c|c|c|}
\hline $\begin{array}{l}\text { Site } \\
\text { Code }\end{array}$ & Site Name & $\begin{array}{l}\text { Geographical } \\
\text { Coordinates }\end{array}$ & $\begin{array}{l}\text { Distance From } \\
\text { Sampling } \\
\text { locations }(\mathbf{k m})\end{array}$ & Description \\
\hline 1 & Dak Patthar & $\begin{array}{l}30.502487 \mathrm{~N} \\
77.798393 \mathrm{E}\end{array}$ & Start point & $\begin{array}{l}\text { Pristine condition of river, small fishes/ } \\
\text { organisms, ingenious change in terrain } \\
\text { profile observed. }\end{array}$ \\
\hline 2 & Paonta Sahib & $\begin{array}{l}30.433365 \mathrm{~N} \\
77.620863 \mathrm{E}\end{array}$ & 23 & $\begin{array}{l}\text { Remnants of devout offerings, settlements } \\
\text { disposing waste into river }\end{array}$ \\
\hline 3 & Kalanour & $\begin{array}{l}30.069167 \mathrm{~N} \\
77.351698 \mathrm{E}\end{array}$ & 79 & $\begin{array}{l}\text { NHAI } 4 \text { lane road network under } \\
\text { construction ,Metallurgical industries, } \\
\text { Thermal plant fly ash pond, SAIL plant, } \\
\text { cremation site }\end{array}$ \\
\hline 4 & Cullackpur & $\begin{array}{l}28.858605 \mathrm{~N} \\
77.209396 \mathrm{E}\end{array}$ & 175 & $\begin{array}{l}\text { Water turns dark brown; stingy odour, } \\
\text { cattails, flowering rush and bulrushes. } \\
\text { Stonewort, plankton algae, Water } \\
\text { Hyacinth, mosses, Myriophyllum (milfoil) }\end{array}$ \\
\hline 5 & Sonia Vihar & $\begin{array}{l}28.721756 \mathrm{~N} \\
77.241404 \mathrm{E}\end{array}$ & 29 & $\begin{array}{l}\text { Delhi Jal Board Plant, Entry point of river } \\
\text { into Delhi }\end{array}$ \\
\hline 6 & $\begin{array}{l}\text { Najafgarh } \\
\text { Drain }\end{array}$ & $\begin{array}{l}28.706072 \mathrm{~N} \\
77.231996 \mathrm{E}\end{array}$ & 7.7 & $\begin{array}{l}\text { Confluence of river with Najafgarh drain } \\
\text { (the major polluting drain), Signature } \\
\text { bridge constructional waste dump on site, } \\
\text { dark black water, extreme odour }\end{array}$ \\
\hline 7 & $\begin{array}{l}\text { Delhi Old } \\
\text { Bridge }\end{array}$ & $\begin{array}{l}28.661981 \mathrm{~N} \\
77.252145 \mathrm{E}\end{array}$ & 7.7 & $\begin{array}{l}\text { Densely populated, largest concentration } \\
\text { of small scale industries }\end{array}$ \\
\hline 8 & $\begin{array}{l}\text { Yamuna } \\
\text { Bank }\end{array}$ & $\begin{array}{l}28.615742 \mathrm{~N} \\
77.255569 \mathrm{E}\end{array}$ & 9 & $\begin{array}{l}\text { Drain of IP Power plant, blackish color. } \\
\text { stingy odour }\end{array}$ \\
\hline 9 & $\begin{array}{l}\text { Sarae Kale } \\
\text { Khan }\end{array}$ & $\begin{array}{l}28.596835 \mathrm{~N} \\
77.268218 \mathrm{E}\end{array}$ & 8.2 & $\begin{array}{l}\text { Weed plants were found in large number, } \\
\text { stingy odour with inorganic waste. }\end{array}$ \\
\hline 10 & $\begin{array}{l}\text { Okhla Bird } \\
\text { Sanctuary }\end{array}$ & $\begin{array}{l}28.535793 \mathrm{~N} \\
77.328382 \mathrm{E}\end{array}$ & 14 & $\begin{array}{l}\text { Confluence of Shahdara drain }\left(2^{\text {nd }} \text { major }\right. \\
\text { polluting drain) with Yamuna, cow shed, } \\
\text { direct release of untreated waste. }\end{array}$ \\
\hline 11 & Kaliya Ghat & $\begin{array}{l}27.582988 \mathrm{~N} \\
77.687496 \mathrm{E}\end{array}$ & 144 & $\begin{array}{l}\text { Brown color water, untreated waste } \\
\text { outlets, }\end{array}$ \\
\hline 12 & $\begin{array}{l}\text { Gokul } \\
\text { Barrage }\end{array}$ & $\begin{array}{l}27.439817 \mathrm{~N} \\
77.717803 \mathrm{E}\end{array}$ & 29 & $\begin{array}{l}\text { Water color turns green, algal growth, } \\
\text { bathing and open defecation. }\end{array}$ \\
\hline 13 & Poiya Ghat & $\begin{array}{l}27.254229 \mathrm{~N} \\
78.022088 \mathrm{E}\end{array}$ & 67 & $\begin{array}{l}\text { Stingy odour, agricultural activities and } \\
\text { dumps of waste. }\end{array}$ \\
\hline 14 & Rambagh & $\begin{array}{l}27.205341 \mathrm{~N} \\
78.036348 \mathrm{E}\end{array}$ & 8 & $\begin{array}{l}\text { Cremation site, water slightly clear in } \\
\text { brown color, no fishes or organism; exit } \\
\text { point of Agra. }\end{array}$ \\
\hline
\end{tabular}




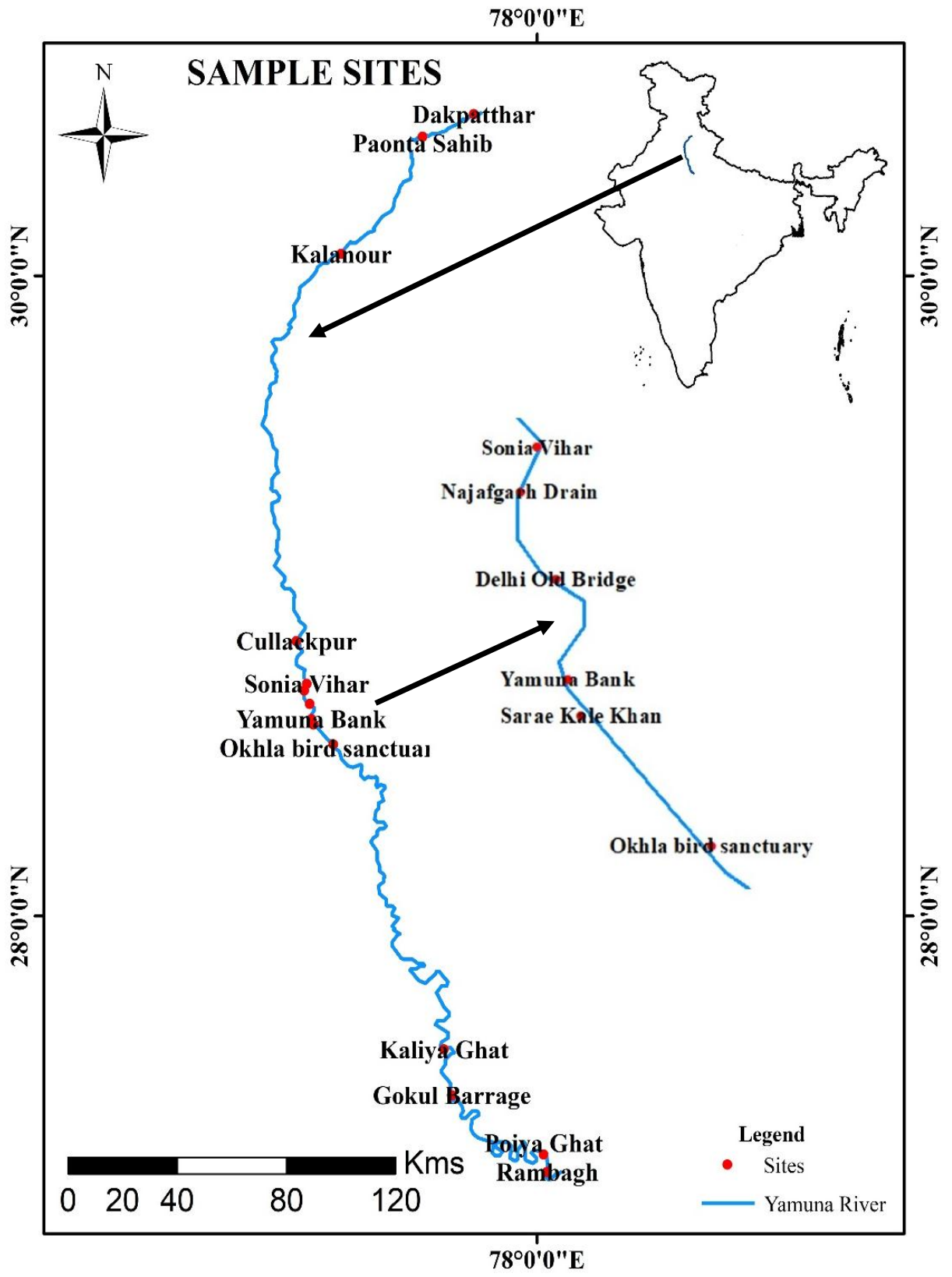

Fig.1 Location map of the study area and sampling points in parts of the River Yamuna from Dak Patthar to Agra.

\section{MATERIAL AND METHODS}

The water samples were collected from the river with evident point sources of pollution in the satellite imageries and concentrations of anthropogenic activities. Two sets of sterilized High-Density Polyethylene Bottle (HDPE) with a capacity of $500 \mathrm{ml}$ each were filled from a $20 \mathrm{~cm}$ river water depth. The coordinates of the sites were taken with Garmin eTrex 10 Global Positioning System. In-situ parameters (pH, 
Temperature, Total Dissolved Solids, Electric Conductivity, Dissolved Oxygen, Turbidity) were measured using a Horiba Multi-parameter probe. The samples preserved at $4^{\circ} \mathrm{C}$ after acidifying with concentrated Nitric Acid were transferred to the laboratory for further analysis as per the standard procedure. NovAA350Analytikjena Atomic Absorption Spectrophotometer (AAS) was used for Heavy Metal detection of Iron, Zinc, Manganese, and Copper and an average of three replicates were recorded.

For calculating Heavy Metal Pollution Index (HPI) values; Eq.1. (Mohan et al 1996; Ichwana, et al. 2016) weighted arithmetic averages of the concentrations were used

$$
\mathbf{H P I}=\sum_{i=1}^{n} W i Q i / \sum_{i=1}^{n} W i
$$

Wherein, Wi is the unit weightage defined as the reciprocal value of Si which is the maximum permissible limit for irrigation purposes of water as per FAO (Ayers and Westcot, 1994). The number of parameters $n$ and Qi being the sub-index of the ith parameter are calculated as in Eq.2. Further, Mi has monitored values of the heavy metal and Si the standard value for the i-th parameter. Both these values are in ppm.

$$
Q i=\sum_{n=1}^{n} \quad \frac{M i}{S i} * 100
$$

Further Heavy Metal Evaluation Index (HEI) is used to obtain the overall quality of water concerning the heavy metal concentrations measured. $\boldsymbol{H E I}=\sum_{i=0}^{n} H c / H m a c$

Where in; Hc and Hmac are the monitored value and maximum admissible concentration (mac) of the ith parameter (Pundir et al., 2018). Table 3 was used for the calculation of the HPI and HEI.

Table 3: Heavy Metals Permissible Concentration by World agencies and Standard values for the indices computation.

\begin{tabular}{|c|c|c|c|c|c|c|c|c|c|c|}
\hline $\begin{array}{c}\text { Heavy } \\
\text { Metals }\end{array}$ & $\begin{array}{c}\text { US } \\
\text { EPA, } \\
\mathbf{2 0 0 8}\end{array}$ & $\begin{array}{c}\text { WHO } \\
\mathbf{2 0 0 8}\end{array}$ & $\begin{array}{c}\text { EU } \\
\mathbf{1 9 9 8}\end{array}$ & $\begin{array}{c}\text { BIS (ISO: } \\
\mathbf{1 0 5 0 0}) \mathbf{2 0 1 2}\end{array}$ & ICMR1975 & $\begin{array}{c}\text { CPCB } \\
\mathbf{2 0 1 2}\end{array}$ & W & S & I & MAC \\
\hline & $(\boldsymbol{\mu g} / \mathbf{l})$ & $(\boldsymbol{\mu g} / \mathbf{l})$ & $(\boldsymbol{\mu g} / \mathbf{l})$ & $(\boldsymbol{\mu g} / \mathbf{l})$ & $(\boldsymbol{\mu g} / \mathbf{l})$ & $(\boldsymbol{\mu g} / \mathbf{l})$ & & & & \\
\hline $\mathrm{Fe}$ & 300 & NGL $^{*}$ & 200 & 300 & 300 & 300 & 0.005 & 300 & 200 & 200 \\
\hline $\mathrm{Zn}$ & 5000 & NGL $^{* *}$ & $\mathrm{NM}$ & 5000 & 5000 & 5000 & 0.0002 & 5000 & 3000 & 5000 \\
\hline $\mathrm{Mn}$ & 50 & 400 & 50 & 100 & 100 & 2000 & 0.02 & 100 & 500 & 50 \\
\hline $\mathrm{Cu}$ & 1300 & 2000 & 2000 & 50 & 50 & 3000 & 0.001 & 1000 & 2000 & 1000 \\
\hline
\end{tabular}

W Weightage (1/MAC) (adopted from Edet and Offiong 2002),S standard permissible in ppb, I highest permissible in ppb, MAC maximum admissible concentration/upper permissible.

NM-Not Mentioned; NGL* No Guideline, because it is not of health concern at concentrations normally observed in drinking water, but may affect the acceptability of water at concentration above $300 \mu \mathrm{g} / \mathrm{L} ; N G L^{* *}$ No Guideline, because it occurs in drinking-water at concentrations well below those at which toxic effects may occur; USEPA-United States Environment Protection Agency; WHO- World Health Organization; EU- European Standards; BIS- Bureau of Indian Standards; ICMRIndian Council of Medical Research; CPCB-Central Pollution Control Board.

Source: Kaur \& Mehra, 2012; Saha \& Paul, 2016 
Contamination index (Cd) as Backman et al 1997 demonstrated analyzes the cumulative effect of various parameters on the quality of water for domestic purposes. This index is the sum of contamination factors of the individual parameters beyond their permissible standard values as represented in Eqn. below.

$$
\boldsymbol{C d}=\sum_{i=1}^{n} c f i
$$

Where $C f i=C A i / C N i-1$.

The Cfi, CAi, and CNi represent the contamination factor, analytical value, and upper permissible concentration, respectively, of the ith component. $\mathrm{N}$ denotes the 'normative value'; values for $\mathrm{CNi}$ were taken as MACs given in Table 3.

Principal component analysis (PCA) interprets the variance of large datasets without losing their dimensionalities using the Eigenvalue and Eigenvectors of the original variable. PCA is one of the best multivariate statistical techniques for extracting linear relationships among a set of variables (Simeonov et al 2003).

Cluster Analysis (CA- hierarchical clustering); primary objective is to identify relatively homogenous groups or clusters of objects based on their similarities/dissimilarities (Wai et al 2010). In the clustering procedure ztransformation of the raw data was performed with squared Euclidean distance as a similarity measure and Ward's method of the linkage.

\section{RESULTS AND DISCUSSION}

The onsite observations were noted and described in Table2. The results derived are summarized in Table 4; with average concentrations of the heavy metals; total metal load at the sites and the physical parameters measured namely $\mathrm{pH}$, Temperature, and Total Dissolved Solids. The $\mathrm{pH}$ values range 6.91-7.86 with the average temperature being $20.7^{\circ} \mathrm{C}$. The average Total Dissolved Solids (TDS) was $468.21 \mathrm{ppm}$ with a maximum of $885 \mathrm{ppm}$ at Najafgarh Drain site and a minimum of 79 at Dak Patthar site. The average concentrations in parts per billion of the metals were in the increasing order $\mathrm{Cu}>\mathrm{Fe}>\mathrm{Mn}>\mathrm{Zn}$; with values 292.7> 309.23>475.15> 3643.9. The maximums were Copper 892.2 ppb (site12), Iron 754.7 ppb (site 3), Manganese 982.2 ppb(Site 10) while Zinc 8146.9ppb (site 9). Concerning Total Metal Load; Sarae kale khan site was most contaminated with $9303.9 \mathrm{ppb}$. However, the average value of Metal Load was 4720.99 ppb. 
Table 4: Site wise Physical and Heavy Metal Concentration load of River Yamuna.

\begin{tabular}{|c|c|c|c|c|c|c|c|c|c|}
\hline $\begin{array}{l}\text { Site } \\
\text { No. }\end{array}$ & Location & pH & $\begin{array}{c}\text { Temp } \\
\left({ }^{\circ} \mathbf{C}\right)\end{array}$ & $\begin{array}{c}\text { TDS } \\
(\mathbf{p p m})\end{array}$ & $\begin{array}{c}\text { Copper } \\
\text { (in } \\
\text { ppb) }\end{array}$ & $\begin{array}{c}\text { Iron (in } \\
\text { ppb) }\end{array}$ & $\begin{array}{c}\text { Manganese } \\
\text { (in ppb) }\end{array}$ & $\begin{array}{l}\text { Zinc } \\
\text { (in } \\
\text { ppb) }\end{array}$ & $\begin{array}{c}\text { Metal } \\
\text { Load (ppb) }\end{array}$ \\
\hline 1 & Dak Patthar & 7.86 & 19.8 & 79 & 25.5 & 67.7 & 217 & 1014.3 & 1324.5 \\
\hline 2 & Paonta Sahib & 7.3 & 19.7 & 175 & 3.1 & 219.1 & 262 & 1101.4 & 1585.6 \\
\hline 3 & Kalanour & 7.44 & 21 & 184 & 324.7 & 388.4 & 119.2 & 1648.2 & 2480.5 \\
\hline 4 & Cullackpur & 7.53 & 21 & 247 & 84.9 & 754.7 & 123.5 & 1624.1 & 2587.2 \\
\hline 5 & Sonia Vihar & 7.21 & 20.5 & 312 & 47.2 & 289.1 & 261.8 & 3137 & 3735.1 \\
\hline 6 & Najafgarh Drain & 6.91 & 19.8 & 885 & 195.9 & 267.1 & 321.5 & 3178.9 & 3963.4 \\
\hline 7 & Delhi Old Bridge & 7.2 & 19.8 & 559 & 820.3 & 393.8 & 775.7 & 3168.5 & 5158.3 \\
\hline 8 & Yamuna Bank & 6.98 & 21.7 & 614 & 253.7 & 313.5 & 778.1 & 7189.7 & 8535 \\
\hline 9 & Sarae Kale Khan & 7.49 & 19.8 & 633 & 120.8 & 219.5 & 816.7 & 8146.9 & 9303.9 \\
\hline 10 & $\begin{array}{l}\text { Okhla Bird } \\
\text { Sanctuary }\end{array}$ & 7.45 & 19.2 & 586 & 146.7 & 183.4 & 982.2 & 2977.4 & 4289.7 \\
\hline 11 & Kaliya Ghat & 7.51 & 21.1 & 526 & 111.6 & 197.1 & 949.5 & 6257.4 & 7515.6 \\
\hline 12 & Gokul Barrage & 7.38 & 24 & 528 & 892.2 & 364.2 & 920.5 & 1597.7 & 3774.6 \\
\hline 13 & Poiya Ghat & 7.55 & 21 & 679 & 783.9 & 283.1 & 48.9 & 6038.7 & 7154.6 \\
\hline 14 & Rambagh & 7.16 & 21.7 & 548 & 287.3 & 388.6 & 75.6 & 3934.4 & 4685.9 \\
\hline
\end{tabular}

The Site wise results of the three indices: HPI; HEI; Cd for the study area are compiled in Table 5. The mean values of the indices are HPI as 551.4; HEI as 12.07 and $\mathrm{Cd}$ as 8.07. Further, the correlation of the three indices with metal concentrations being studied to a significant level of $>0.5$ was noted in Table 6 . A highly positive correlation of Manganese with the three indices was observed. Iron showed a negative correlation with the indices. PCA with Loading values $>0.3$ were considered. It was observed from Table 7 that PC1 having eigenvalue as 55.49 had a maximum variance of $98.85 \%$. The other two PC2 and PC 3 had $0.76 \%$ and $0.38 \%$ of the variance. Cluster Analysis cophenetic correlation coefficient was noted to be 0.7776. Fig2 shows the 14 sites divided into two clusters according to the metal concentrations. The average value of water quality parameters for each cluster is listed in Table 8 . 
Table 5: Sitewise Results of the three indices (HPI; HEI; $\mathrm{C}_{\mathrm{d}}$ ) for the study area.

\begin{tabular}{|c|c|c|c|}
\hline S.No & HPI & HEI & $\mathrm{C}_{\mathrm{d}}$ \\
\hline 1 & 188.74 & 4.91 & 0.91 \\
\hline 2 & 286.98 & 6.56 & 2.56 \\
\hline 3 & 175.84 & 4.98 & 0.98 \\
\hline 4 & 261.19 & 6.65 & 2.65 \\
\hline 5 & 314.71 & 7.36 & 3.36 \\
\hline 6 & 372.41 & 8.60 & 4.60 \\
\hline 7 & 1008.96 & 18.94 & 14.94 \\
\hline 8 & 925.23 & 18.82 & 14.82 \\
\hline 9 & 865.93 & 19.18 & 15.18 \\
\hline 10 & 991.18 & 21.30 & 17.30 \\
\hline 11 & 975.87 & 21.34 & 17.34 \\
\hline 12 & 1155.77 & 21.44 & 17.44 \\
\hline 13 & 75.94 & 4.39 & 0.39 \\
\hline 14 & 120.90 & 4.53 & 0.53 \\
\hline Max & 1155.77 & 21.44 & 17.44 \\
\hline Min & 75.94 & 4.39 & 0.39 \\
\hline Mean & 551.40 & 12.07 & 8.07 \\
\hline
\end{tabular}

Table 6: Correlation analysis of the studied metal concentration and indices.

\begin{tabular}{|c|c|c|c|}
\hline & HPI & HEI & $\mathrm{C}_{\mathrm{d}}$ \\
\hline $\mathrm{Cu}$ & 0.28493 & 0.232471 & 0.232471 \\
\hline $\mathrm{Fe}$ & -0.13795 & -0.17139 & -0.17139 \\
\hline $\mathrm{Mn}$ & $\mathbf{0 . 9 8 2 3 0 6}$ & $\mathbf{0 . 9 9 1 6 8 7}$ & $\mathbf{0 . 9 9 1 6 8 7}$ \\
\hline $\mathrm{Zn}$ & 0.324095 & 0.409178 & 0.409178 \\
\hline $\mathrm{HPI}$ & 1 & $\mathbf{0 . 9 9 1 0 4 8}$ & $\mathbf{0 . 9 9 1 0 4 8}$ \\
\hline $\mathrm{HEI}$ & $\mathbf{0 . 9 9 1 0 4 8}$ & 1 & $\mathbf{0 . 9 9 1 0 4 8}$ \\
\hline $\mathrm{Cd}$ & $\mathbf{0 . 9 9 1 0 4 8}$ & 1 & 1 \\
\hline
\end{tabular}

Significant levels $>0.5$ 
Table 7: Principal Component analysis for the surface water sample

\begin{tabular}{|c|c|c|c|}
\hline Sites No. & PC 1 & PC 2 & PC 3 \\
\hline 1 & 0.061618 & -0.08742 & 0.032543 \\
\hline 2 & 0.063501 & -0.07648 & 0.18533 \\
\hline 3 & 0.091098 & 0.2239 & 0.068677 \\
\hline 4 & 0.086352 & 0.24878 & 0.60069 \\
\hline 5 & 0.19721 & 0.043661 & 0.21548 \\
\hline 6 & 0.19585 & 0.049666 & 0.066345 \\
\hline 7 & 0.16849 & -0.01117 & -0.37295 \\
\hline 8 & 0.4535 & -0.08894 & 0.050419 \\
\hline 9 & 0.52236 & -0.15872 & 0.081089 \\
\hline 10 & 0.17295 & -0.48798 & 0.006428 \\
\hline 11 & 0.39394 & -0.34198 & 0.058621 \\
\hline 12 & 0.05943 & -0.16274 & -0.47086 \\
\hline 13 & 0.37825 & 0.58683 & -0.40376 \\
\hline 14 & 0.24606 & 0.33311 & 0.10861 \\
\hline Eigen value & 55.491 & 0.426999 & 0.217741 \\
\hline Cumulative $\%$ of variance & 98.85 & 99.61 & 100.00 \\
\hline$\%$ of variance & 98.851 & 0.76065 & 0.38788 \\
\hline
\end{tabular}

Loading values $>0.3$ were considered

Table 8: Average value of water quality parameters for each cluster

\begin{tabular}{|c|c|c|}
\hline Parameters & Cluster 1 $(1,2,3,4,5,6,7)$ & Cluster $2(8,9,10,11,12,13,14)$ \\
\hline $\mathrm{Cu}(\mathrm{ppb})$ & 214.51 & 370.88 \\
\hline $\mathrm{Fe}(\mathrm{ppb})$ & 339.98 & 278.48 \\
\hline $\mathrm{Mn}(\mathrm{ppb})$ & 297.24 & 653.07 \\
\hline $\mathrm{Zn}(\mathrm{ppb})$ & 2124.62 & 5163.17 \\
\hline
\end{tabular}




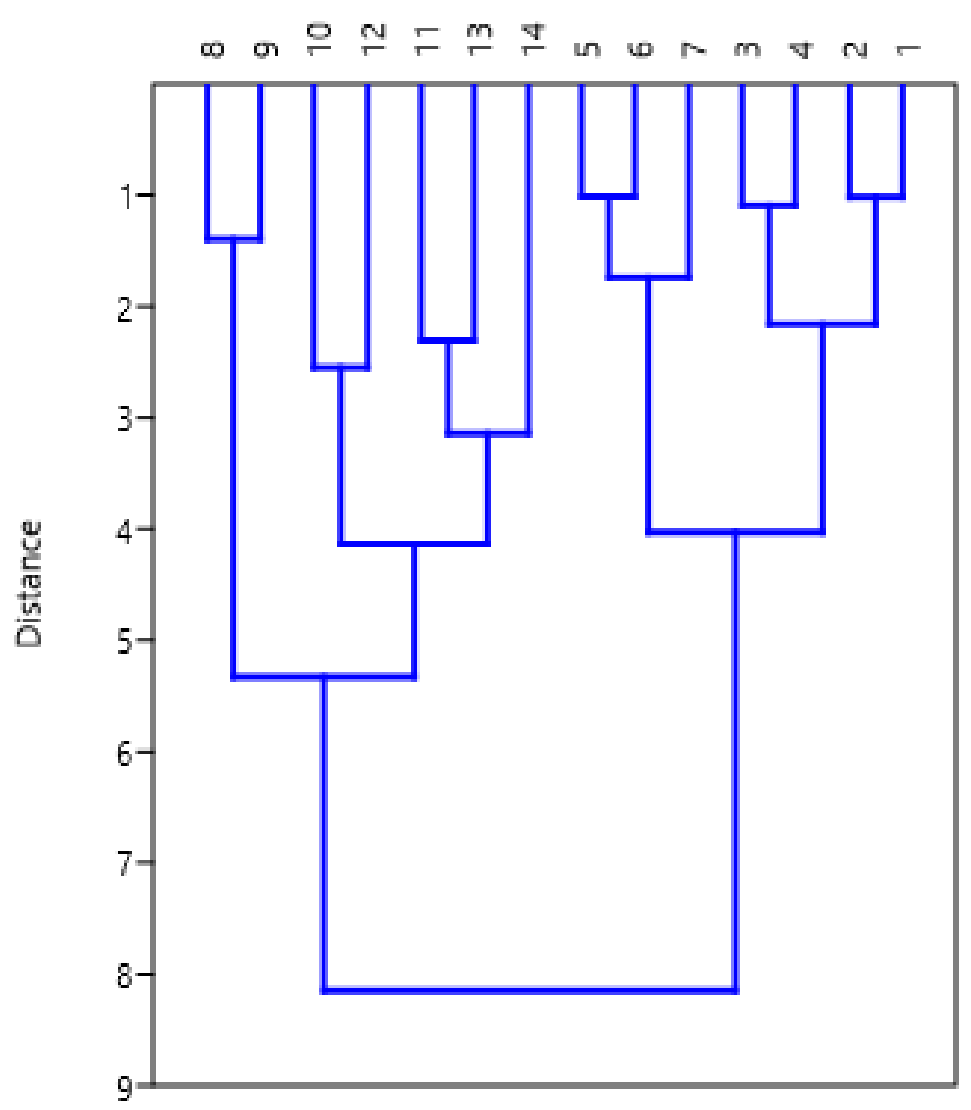

Fig. 2 The Cluster Analysis of heavy metal values of different sampling locations.

The HPI values between $0-25$ are considered to be very good and progressively degrade above 75. The critical value is considered to be 100. Bhardwaj et al, 2017 had 6 sites alike this study in Delhi; with overall heavy metal pollution index value calculated as 1492. In this study, the HPI was maximum at Gokul Barrage site with 1155.77. Further, Pal et al 2017 studied the 2 sites of Mathura similar to this study wherein the distance of $67 \mathrm{~km}$ led to settling of metals in sediments and decreased the HPI value from the previous noted values. In terms of HEI 4.39 at Poiya Ghat; site 13 was noted to be least associated with least $\mathrm{Cd}$ of 0.39 . With the help of HEI, the values of HPI and Cd were correlated. The PCA was performed to know the PC which was PC1 at 55.491 Eigenvalue. The two clusters of site groups with lesser and more concentration of metals helped to analyze the use of metals in the catchment. As supported by Aktar et al., 2010 often a reduction in heavy metal toxicity is credited to high pH value. Similarly, Woji Creek studied by Orji et al in 2019 had HPI noted as 329.358. Site-specific higher HPI values are in agreement with Pal et al and Bhardwaj et al 2017 for the Yamuna river stretch.

The confluence of the river with Najafgarh drain marked a sweeping increase in Copper concentration from $47.2 \mathrm{ppb}$ at Sonia Vihar site to $195.9 \mathrm{ppb}$ at Najafgarh drain site and further $820.3 \mathrm{ppb}$ at Delhi Old Bridge site which is a densely populated 
area with the largest concentration of small scale industries. From the above results, it is clear that the Dak Patthar site reports the most pristine condition of the river with the least heavy metal pollution. The segment covering Delhi was the most polluted area. The Najafgarh Drain and Shahdara drain at Okhla bird sanctuary were seen to be major sources of pollution as there is an intense increase in HPI values beyond the sites which were in alignment with Bhardwaj et al 2017.

In this study an attempt was made to assess pollution and mark their impact and probable sources of the river pollution through the three site-wise indices namely; HPI, HEI, and Cd. The analysis of HPI and Cd; where mean values were 551.40 for HPI and 8.07 was for $\mathrm{Cd}$; showed extreme results that could be credited to the variation in the methodology of the evaluation process and metal concentration. With the use of HEI, the relationship of a significant level $>0.5$ was established between the parameters. With the help of PCA, the sites were clustered into low and high concentrations of metals. Results indicated the possible sources of contamination through untreated municipal and industrial waste; domestic effluents brought by the major drains in the Delhi segment and the dispersed agricultural runoff from the farmland. The agricultural runoff containing fertilizers, the stormwater runoff, leakages through malfunctioning Sewage Treatment Plants, laundry activities, immersions of idols, and sacred offerings together contributed to a high index value. Suggestions include checks measures on discharge of untreated domestic and industrial waste, reduction in fertilizers consumption while promoting organic techniques, separate ponds for idols immersion and sacred offerings. Standardization of dumping of domestic waste; agricultural and underdone sewage runoff into the river more meticulously.

\section{Acknowledgement:}

I, Rahat Zehra, would like to concede and thank Dr. Madhulika Singh and Dr. Jyoti Verma for their untiring efforts in guiding me through all sample collections; statistical analysis and interpretation. I would like to thank Dr. Kuldeep Singh, Director, Amity Center for Soil Sciences for his personal guidance and the valuable help given by his team. The efforts of National Testing Laboratory Private Ltd, Delhi were commendable.

\section{Compliance with Ethical Standards:}

It is hereby declared that the authors have no conflict of interest. The research work did not include Human or animal participants by any authors. There was an informed consent throughout the research work and all the applicable guidelines were followed.

\section{Declarations:}

This is to declare and confirm that the present work was performed by Miss. RAHAT ZEHRA (Corresponding First Author) as part of her Ph.D. research under the 
guidance of Dr. Madhulika Singh (Ph.D. Supervisor, Advisor, Amity Institute of Geo Informatics and Remote Sensing, Amity University, Noida, U.P) and Dr. Jyoti Verma (Co-Guide, Assistant Professor, University of Allahabad, Prayagraj, U.P).

\section{REFERENCES}

[1] Venkata Mohan, S., Nithila, P., \&Jayarama Reddy, S. (1996) Estimation of heavy metals in drinking water and development of heavy metal pollution index. Journal of Environmental Science and Health - Part A Toxic/Hazardous Substances and Environmental Engineering, 31(2), 283-289. https://doi.org/10.1080/10934529609376357

[2] Singh, K. P., Mohan, D., Singh, V. K., \& Malik, A. (2005). Studies on distribution and fractionation of heavy metals in Gomti river sediments - A tributary of the Ganges, India. Journal of Hydrology, 312(1-4), 14-27. https://doi.org/10.1016/j.jhydrol.2005.01.021

[3] Begum, A., Ramaiah, M., Harikrishna, Khan, I., \&Veena, K. (2009). Heavy metal pollution and chemical profile of Cauvery river water. E-Journal of Chemistry, 6(1), 47-52. https://doi.org/10.1155/2009/154610

[4] Gupta, A., Rai, D. K., Pandey, R. S., \& Sharma, B. (2009). Analysis of some heavy metals in the riverine water, sediments and fish from river Ganges at Allahabad. Environmental Monitoring and Assessment, 157(1-4), 449-458. https://doi.org/10.1007/s10661-008-0547-4

[5] Roy, A., Das, B. K., \& Bhattacharya, J. (2011). Development and Validation of a Spectrophotometric Method to Measure Sulfate Concentrations in Mine Water without Interference. In Mine Water and the Environment (Vol. 30, Issue 3). https://doi.org/10.1007/s10230-011-0140-x

[6] Parmar, D. L., \&Keshari, A. K. (2012). Sensitivity analysis of water quality for Delhi stretch of the River Yamuna, India. Environmental Monitoring and Assessment, 184(3), 1487-1508. https://doi.org/10.1007/s10661-011-2055-1

[7] Kaur, S., \& Mehra, P. (2012). Assessment of Heavy Metals in Summer \& Winter Seasons in River Yamuna Segment Flowing through Delhi, India. Journal of Environment and Ecology, 3(1), 149-165. https://doi.org/10.5296/jee.v3i1.2675

[8] Kumar, M., \&Puri, A. (2012). A review of permissible limits of drinking water. Indian Journal of Occupational and Environmental Medicine, 16(1), 40-44. https://doi.org/10.4103/0019-5278.99696

[9] Duan, W., He, B., Takara, K., Luo, P., Nover, D., Sahu, N., \&Yamashiki, Y. (2013). Spatiotemporal evaluation of water quality incidents in japan between 1996 and 2007. Chemosphere, 93(6), 946-953. https://doi.org/10.1016/j.chemosphere.2013.05.060

[10] Giri, S., \& Singh, A. K. (2014). Assessment of Surface Water Quality Using 
Heavy Metal Pollution Index in Subarnarekha River, India. Water Quality, Exposure and Health, 5(4), 173-182. https://doi.org/10.1007/s12403-0130106-2

[11] Singh, H., Yadav, S., Singh, B. K., Dubey, B., Tripathi, K., Srivastava, V., \& Shukla, D. N. (2013). Assessment of geochemical environment from study of river sediments in the middle stretch of River Ganga at Ghazipur, Buxar and Ballia area. Proceedings of the National Academy of Sciences India Section B - Biological Sciences, 83(3), 371-384. https://doi.org/10.1007/s40011-0120134-x

[12] Bhat, S. A., Meraj, G., Yaseen, S., \&Pandit, A. K. (2014). Statistical Assessment of Water Quality Parameters for Pollution Source Identification in Sukhnag Stream: An Inflow Stream of Lake Wular (Ramsar Site), Kashmir Himalaya. Journal of Ecosystems, 2014, 1-18. https://doi.org/10.1155/2014/898054

[13] Mishra, K., Nayak, P. L., (2014). A Study of Water Pollution in Two Major Rivers in Odisha-Mahanadi and Brahmani. 22(12), 1760-1770. https://doi.org/10.5829/idosi.mejsr.2014.22.12.21634

[14] Panakkal, A., \& Kumar, R. B. B. (2014). Evaluation of the trace metal contamination in sediments of the urban water Channels in Thrissur City, South India. Nature Environment and Pollution Technology, 13(4), 701-706.

[15] Mishra, S., Kumar, A., Yadav, S., \& Singhal, M. K. (2015). Assessment of heavy metal contamination in Kali river, Uttar Pradesh, India. Journal of Applied and Natural Science, 7(2), 1016-1020. https://doi.org/10.31018/jans.v7i2.724

[16] Ahirwar, M. K. (2015). Study of Heavy Metal Pollution from Effluent of Orient Paper Mill ,Amalai , ( Shahdol ), M . P .4(11), 28-38.

[17] Malik, D. S., \&Maurya, P. K. (2014). Heavy metal concentration in water, sediment, and tissues of fish species (Heteropneustisfossilis and Puntius ticto) from Kali River, India. Toxicological and Environmental Chemistry, 96(8), 1195-1206. https://doi.org/10.1080/02772248.2015.1015296

[18] Meneses, M., Concepción, H., \&Vilanova, R. (2016). Joint environmental and economical analysis of wastewater treatment plants control strategies: A benchmark scenario analysis. Sustainability (Switzerland), 8(4). https://doi.org/10.3390/su8040360

[19] Vizcaino, I. P., Carrera, E. V., Sanromán-Junquera, M., Muñoz-Romero, S., Rojo-Álvarez, J. L., \&Cumbal, L. H. (2016). Spatio-temporal analysis of water quality parameters in machángara river with nonuniform interpolation methods. Water (Switzerland), 8(11), 1-17. https://doi.org/10.3390/w8110507

[20] Ichwana, I., Syahrul, S., \& Nelly, W. (2016). Water Quality Index by Using National Sanitation Foundation-Water Quality Index (NSF-WQI) Method at KruengTamiang Aceh. 110-117. https://doi.org/10.21063/ictis.2016.1019 
[21] Trivedi, P., Singh, A., Srivastava, A., Sharma, V. P., Pandey, C. P., Srivastava, L. P., \& Malik, S. (2016). An Assessment of Water Quality of Gomati River Particular Relevant To Physicochemical Characteristics, Pesticide and Heavy Metal. Journal of Engineering Research and Application Www.Ijera.Com, 6(2), 66-75. www.ijera.com

[22] Bhardwaj, R., Gupta, A., \& Garg, J. K. (2017). Evaluation of heavy metal contamination using environmetrics and indexing approach for River Yamuna, Delhi stretch, India. Water Science, 31(1), 52-66. https://doi.org/10.1016/j.wsj.2017.02.002

[23] Hussain, J., Husain, I., Arif, M., \& Gupta, N. (2017). Studies on heavy metal contamination in Godavari river basin. Applied Water Science, 7(8), 45394548. https://doi.org/10.1007/s13201-017-0607-4

[24] Khan, M. Y. A., Gani, K. M., \&Chakrapani, G. J. (2017). Spatial and temporal variations of physicochemical and heavy metal pollution in Ramganga River - a tributary of River Ganges, India. Environmental Earth Sciences, 76(5). https://doi.org/10.1007/s12665-017-6547-3

[25] River Data Directorate Planning \& Development Organisation. (2014). Status of Trace and Toxic Metals in Indian Rivers. In Central Water Commission (Issue May). http://www.indiaenvironmentportal.org.in/files/file/status_trace_toxic_materia 1s_indian_rivers.pdf

[26] Sahoo, M. M., \&Patra, K. C. (2019). Spatiotemporal evaluation of trace elements in river water using multivariate methods. Human and Ecological Risk Assessment, 25(5), 1311-1335. https://doi.org/10.1080/10807039.2018.1488214

[27] SeifSeif, D., Nasr, M., R. Soliman, M., Moustafa, M., \&Elbarki, W. (2018). Water quality analysis and model simulation for the second largest polluted lake in Egypt. International Journal of Engineering \& Technology, 7(3), 1762. https://doi.org/10.14419/ijet.v7i3.13593

[28] Rawat, K. S., \& Singh, S. K. (2018). Water Quality Indices and GIS-based evaluation of a decadal groundwater quality. Geology, Ecology, and Landscapes, 2(4), 240-255. https://doi.org/10.1080/24749508.2018.1452462

[29] Sharma, V., \& Singh, P. (2018). Correlation Study on Physicochemical Parameters of River Ganga during Different Seasons in Haridwar. International Journal of Research in Advent Technology, 6(9), 2261-2272.

[30] Singh, A. N., Shrivastava, R., Mohan, D., \& Kumar, P. (2018). Assessment of Spatial and Temporal Variations in Water Quality Dynamics of River Ganga in Varanasi. Pollution, 4(2), 239-250. https://doi.org/10.22059/poll.2017.240626.310

[31] Sharma, B. B., \&Sarma, H. P. (2018). Assessment of heavy metal pollution in a Himalayan river using multivariate statistical tools: a case study of the 
Kameng River in Arunachal Pradesh, India. Arabian Journal of Geosciences, 11(12). https://doi.org/10.1007/s12517-018-3556-9

[32] Singh, H., Kushwaha, A., \& Shukla, D. N. (2018). Assessment of ecoenvironmental geochemistry of heavy metals pollution of the river Gandak, a major tributary of the river Ganga in Northern India. AIP Conference Proceedings, 1952. https://doi.org/10.1063/1.5032000

[33] DepartemenPermukimandanPrasarana Wilayah. (2003). Clean Water Standards. DitjenCiptaKarya, August, 597-601. https://doi.org/10.31031/EAES.2019.06.000628

[34] Shukla, R. K., Gupta, G. S., Singh, D. P., \& Kumar, M. (2019). Statistical Assessment of the Heavy Metals Pollution of Water and Sediment in the river Mandakini. April.

[35] Jaiswal, M., \& Hussain, J. (2019). Comprehensive evaluation of water quality status for entire stretch of Yamuna River, India.

[36] Liu, X., Zhang, J., Shi, W., Wang, M., Chen, K., \& Wang, L. (2019). Priority pollutants in water and sediments of a river for control basing on benthic macroinvertebrate community structure. Water (Switzerland), 11(6). https://doi.org/10.3390/w11061267

[37] Yadav, A., \& Khandegar, V. (2019). Dataset on assessment of River Yamuna, Delhi, India using indexing approach. Data in Brief, 22, 1-10. https://doi.org/10.1016/j.dib.2018.11.130

[38] Kumar, D., Malik, D. S., Kumar, N., Gupta, N., \& Gupta, V. (2019). Spatial changes in water and heavy metal contamination in water and sediment of river Ganga in the river belt Haridwar to Kanpur. Environmental Geochemistry and Health, 8. https://doi.org/10.1007/s10653-019-00471-8

[39] Li, M., Zhang, Q., Sun, X., Karki, K., Zeng, C., Pandey, A., Rawat, B., \& Zhang, F. (2020). Heavy metals in surface sediments in the trans-Himalayan Koshi River catchment: Distribution, source identification and pollution $\begin{array}{llll}\text { assessment. } & \text { Chemosphere, } & 244, & \end{array}$ https://doi.org/10.1016/j.chemosphere.2019.125410

[40] Pant, R. R., Zhang, F., Rehman, F. U., Koirala, M., Rijal, K., \&Maskey, R. (2020). Spatiotemporal characterization of dissolved trace elements in the Gandaki River, Central Himalaya Nepal. Journal of Hazardous Materials, 389, 121913. https://doi.org/10.1016/j.jhazmat.2019.121913

[41] Ghosh, A., \&Manchanda, N. (2019). Phytoremediation of Heavy Metals from Water of Yamuna River by Tagetespatula, Bassicascoparia, Portulaca grandiflora. Asian Plant Research Journal, 2(2), 1-14. https://doi.org/10.9734/aprj/2019/v2i230042

[42] Bhuyan, M. S., Bakar, M. A., Rashed-Un-Nabi, M., Senapathi, V., Chung, S. Y., \& Islam, M. S. (2019). Monitoring and assessment of heavy metal 
contamination in surface water and sediment of the Old Brahmaputra River, Bangladesh. Applied Water Science, 9(5), 1-13. https://doi.org/10.1007/s13201-019-1004-y

[43] Kalra, K., \&Singhal, D. K. (2019). Article ID: IJCIET_10_02_132 Groundwater Sources along the Course of Swarna River. International Journal of Civil Engineering and Technology (IJCIET), 10(2), 1366-1375. http://www.iaeme.com/IJCIET/index.asp1366http://www.iaeme.com/ijciet/iss ues.asp?JType $=$ IJCIET $\& V T y p e=10 \&$ IType $=02 \mathrm{http}: / / \mathrm{www}$. iaeme.com $/ \mathrm{IJCIET}$ /issues.asp?JType $=$ IJCIET $\&$ VType $=10 \& I T y p e=02$

[44] Ahmad, I., Gandhi, M., Gramoday, C., Chaurasia, S., Gandhi, M., \&Gramoday, C. (2020). Study on Heavy Metal Pollution in Ganga River at Kanpur ( U . P .). January.

[45] Idrees, N., Sarah, R., Tabassum, B., \&FathiAbd_Allah, E. (2020). Evaluation of Some Heavy Metals Toxicity in Channa punctatus and Riverine Water of Kosi in Rampur, Uttar Pradesh, India. Saudi Journal of Biological Sciences. https://doi.org/10.1016/j.sjbs.2020.03.002

[46] Singh, V., Nagpoore, N. K., Jaichand, \&Lehri, A. (2020). Monitoring and assessment of pollution load in surface water of River Ganga around Kanpur, India: A study for suitability of this water for different uses. Environmental $\begin{array}{llll}\text { Technology and Innovation, } 18, & 100676 .\end{array}$ https://doi.org/10.1016/j.eti.2020.100676

[47] U. Singare, P., M. Mishra, R., \& P. Trivedi, M. (2012). Heavy Metal Pollution in Mithi River of Mumbai. Frontiers in Science, 2(3), 28-36. https://doi.org/10.5923/j.fs.20120203.03

[48] Pal, R., Dubey, R. K., Dubey, S. K., \& Singh, A. K. (2017). Assessment of Heavy Metal Pollution through Index Analysis for Yamuna Water in Agra Region, India. International Journal of Current Microbiology and Applied Sciences, 6(12), 1491-1498. https://doi.org/10.20546/ijcmas.2017.612.166

[49] Saha, P., \& Paul, B. (2016). Assessment of Heavy Metal Pollution in Water Resources and their Impacts : A Review. Journal of Basic and Applied Engineering Research, 3(8), 671-675.

[50] Reza, R., Singh, G., Reza, R., \& Singh, G. (2010). Heavy metal contamination and its indexing approach for river water. International Journal of Environmental Science and Technology7(4), 785-792.

[51] Dibofori-Orji, A. N., Ihunwo, O. C., Udo, K. S., Shahabinia, A. R., Onyema, M. O., \&Mmom, P. C. (2019). Spatial and temporal distribution and contamination assessment of heavy metal in Woji Creek. Environmental Research Communications, 1(11), 111003. https://doi.org/10.1088/2515$7620 / a b 4 a 8 c$

[52] Nasrabadi, T. (2015). An index approach to metallic pollution in river waters. International Journal of Environmental Research, 9(1), 385-394. 
https://doi.org/10.22059/ijer.2015.910

[53] Panchayat, L. G. (2018). Water Quality Indices for Assessing Heavy Metals Contamination in Drinking Water Sources of. 6(5), 708-714.

[54] Pal, R., Dubey, R. K., Dubey, S. K., \& Singh, A. K. (2017). Assessment of Heavy Metal Pollution through Index Analysis for Yamuna Water in Agra Region, India. International Journal of Current Microbiology and Applied Sciences, 6(12), 1491-1498. https://doi.org/10.20546/ijcmas.2017.612.166

[55] Biswas, P K, Nasir Uddin, ShaAlam, Tamjid-Us-Sakib, Sharmin Sultana, and Tofayal Ahmed, "Evaluation of Heavy Metal Pollution Indices in Irrigation and Drinking Water Systems of Barapukuria Coal Mine Area, Bangladesh." American Journal of Water Resources, vol. 5, no. 5 (2017): 146-151. doi: 10.12691/ajwr-5-5-2. 